\title{
Zooplankton: A Valuable Environmental Indicator Tool in Reservoir Ecological Management?
}

\author{
Ana Maria Geraldes ${ }^{1 *}$ and Rajeev Pasupuleti ${ }^{2}$ \\ ${ }^{1}$ CIMO, Escola Superior Agrária do Instituto Politécnico de Bragança, Campus de Santa Apolónia, \\ 5300-253 Bragança, Portugal. \\ ${ }^{2}$ Department of Biotechnology, Escola Superior Agrária do Instituto Politécnico de Bragança, Campus \\ de Santa Apolónia, 5300-253 Bragança, Portugal.
}

\section{Authors' contributions}

This work was carried out in collaboration between both authors. Author AMG designed the study, carried out the sample collections and experimental work during 2010 to 2015 and also drafted the preliminary manuscript. Author RP joined in the sample collections during 2015, managed the analyses of the study and reviewed the final manuscript. Both authors read and approved the final

manuscript.

\section{Article Information}

DOI: $10.9734 / A J E E / 2016 / 30662$

Editor(s):

(1) George Tsiamis, Assistant Professor of Environmental Microbiology, Department of Environmental and Natural Resources Management, University of Patras, Agrinio, Greece. Reviewers:

(1) Sophia Barinova, University of Haifa, Israel (2) Suresh Basava, Bapuji Institute of Engineering and Technology, India. (3) Hilal Bulut, Firat University, Turkey. Complete Peer review History: http://www.sciencedomain.org/review-history/17320

\section{Original Research Article}

Received $24^{\text {th }}$ November 2016

Accepted $19^{\text {th }}$ December 2016

Published 23 ${ }^{\text {rd }}$ December 2016

\section{ABSTRACT}

The trends in zooplankton community were assessed in response to the variations in the trophic state and water quality, in Serra Serrada, a shallow reservoir, with seasonal water level fluctuations, located in the Portuguese part of River Douro Basin. Various ratios were also calculated: (1) the ratio of crustacean abundance to rotifer abundance (NCrust/NRot); (2) the ratio of large $(>10 \mu \mathrm{g})$ cladoceran abundance to total cladoceran group abundance (NLargeClad/NClad); (3) The trophic state indices of rotifer abundance. The reservoir's hydrological cycle was characterized by three phases. The maximum level phase lasted from January to the beginning of June, the emptying phase from mid-June to the beginning of September and the minimum level phase between mid-September to the beginning of the first autumn/winter rain events. The highest values for total phosphorus, soluble reactive phosphorus, nitrate, and 
'chlorophyll a' were found during the minimum level phase. Rotifera was the most abundant taxa, except in summer and in autumn where Cladocera and Copepoda were dominant. The ordination space defined by the first two RDA axis accounted for $84.2 \%$ of species-environment relations and represented $25.4 \%$ of the variation in species data. The ratio NCrust/NRot have shown the highest role of rotifers in the zooplankton community in the low level phase. The ratio NLargeClad/NClad displayed a decreasing trend in the abundance of large-sized cladocerans for the same mentioned period. Redundancy analysis (RDA) revealed a strong influence of temperature, chlorophyll a, soluble reactive phosphorous and total phosphorous to the observed significant associations between the zooplankton assemblage and environmental variables. Therefore, these indices are suitable to be used in reservoir management as rapid tools to evaluate the effects of environmental disturbances with a concern to the reservoir ecological integrity.

Keywords: Zooplankton community; environmental indicator; shallow reservoir; seasonal water level fluctuations; nutrients.

\section{INTRODUCTION}

The physical, chemical and biological features in the reservoirs are influenced by seasonal surface-level fluctuations, which are associated with anthropogenic utilization [1,2,3,4,5,6]. Such fluctuations are frequent in the reservoirs located in Portugal, where the seasonal rain events occur in a very irregular pattern. Local human populations of these areas intensively use the stored reservoir water for irrigation, recreation, urban necessities and in hydroelectric power supply. According to the European Union (EU) Water Framework Directive, the ecological status is an expression of the quality of the structure and functioning of aquatic ecosystems. This is assessed by a series of biological quality elements complemented with a set of chemical and hydro-morphological quality data. Zooplankton, despite of not being recognised as a biological quality element, it shows quick responses to environmental changes and so, it can be a valuable indicator of ecological conditions. This value stems from their position in the food web, sandwiched between the top-down regulators (fish) and bottom-up factors (phytoplankton), thus providing information about the relative importance of top-down and bottomup control and their impact on water clarity [7]. Consequently, few studies have been undertaken to assess and understand the responses of zooplankton communities to reservoir water level fluctuations $[8,9,10,11$, $12,13]$. Serra Serrada reservoir is located in the Iberian Peninsula, within the Portuguese part of the River Douro catchment. In this region, precipitation occurs mainly in autumn and winter in an irregular way, with one wet winter usually followed by a few dry ones. This reservoir is subjected to intense water use for hydroelectricity production and for urban supply.
Thus, the hydrological cycle of this reservoir was characterised by the following phases: (1) Maximum level phase, from January to the beginning of June; (2) Emptying phase, from mid June to the beginning of September; (3) Minimum level phase, from mid September to the beginning of the first autumn/winter rain events. Therefore, the objectives of this study were to: (a) examine responses of zooplankton to changes in environmental variables as a consequence of water level fluctuations and (b) compare the values obtained for Carlson's Trophic State Index (based upon physical and chemical variables) to values obtained by several zooplankton metrics, in order to assess the role of zooplankton as an environmental indicator.

\section{MATERIALS AND METHODS}

\subsection{Study Site}

Serra Serrada (Latitude: 4157'12"N; Longitude: $\left.6^{\circ} 46^{\prime} 44^{\prime \prime}\right)$ is located on the granitic bedrock at an altitude of $1300 \mathrm{~m}$ at NE Portugal (Fig. 1). The total capacity of the reservoir, spreading over 25 ha is $1680 \times 10^{3} \mathrm{~m}^{3}$ and it was filled for the first time in 1995 for urban supply and to generate hydroelectric power. As a result of this, accentuated water level fluctuations occur. The annual range of water level variation is between 8 and $10 \mathrm{~m}$ (Fig. 2). The maximum depth is $17 \mathrm{~m}$ and the mean depth is around $6.7 \mathrm{~m}$.

Thermal stratification was observed from June to August/ beginning of September. Disruption of stratification was coincident with the lowest water level. During the period of study this reservoir was considered meso-eutrophic. Direct human influence on S. Serrada impoundment was considered negligible. There are no villages, there has been no agricultural activity in the area 
for approximately 20 years and recreational activities are reduced to a minimum. However, in the catchment basin grazing can be very intense during the summer months. Consequently, this

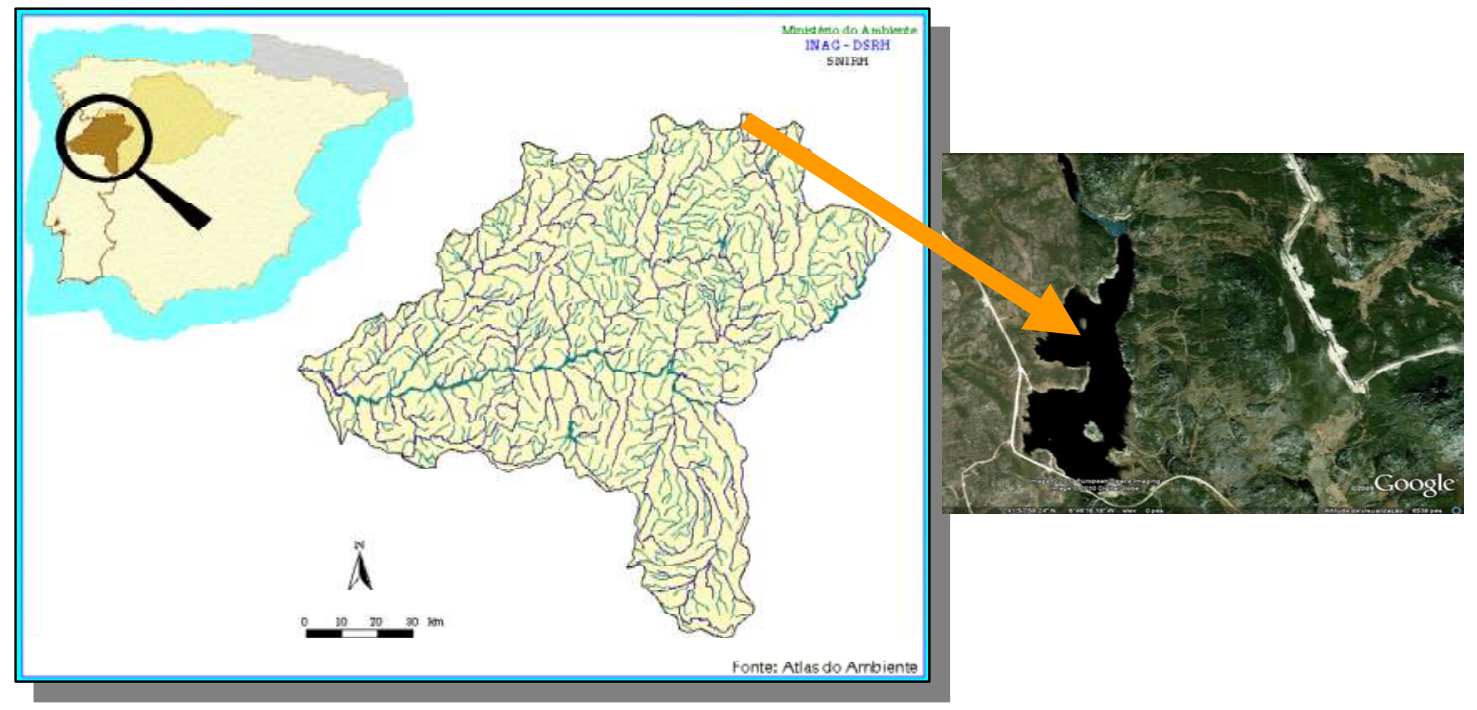

Fig. 1. Location of Serra Serrada Reservoir in the Iberia Peninsula context

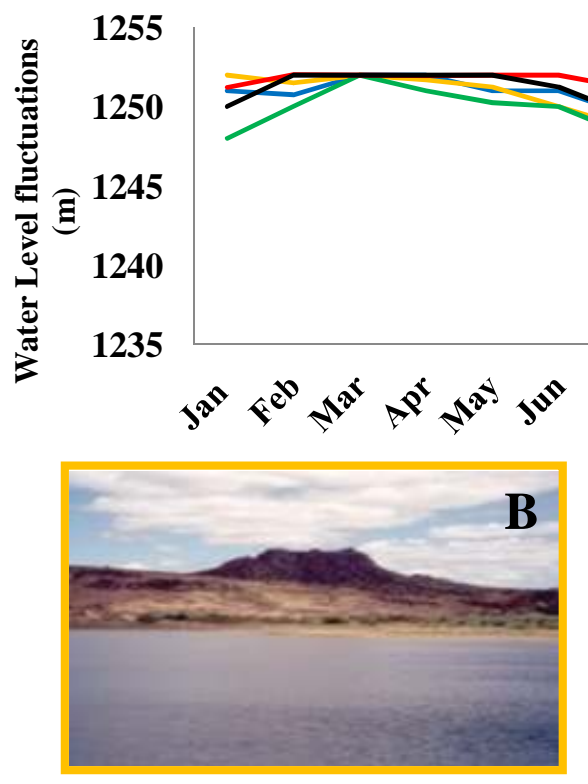

A
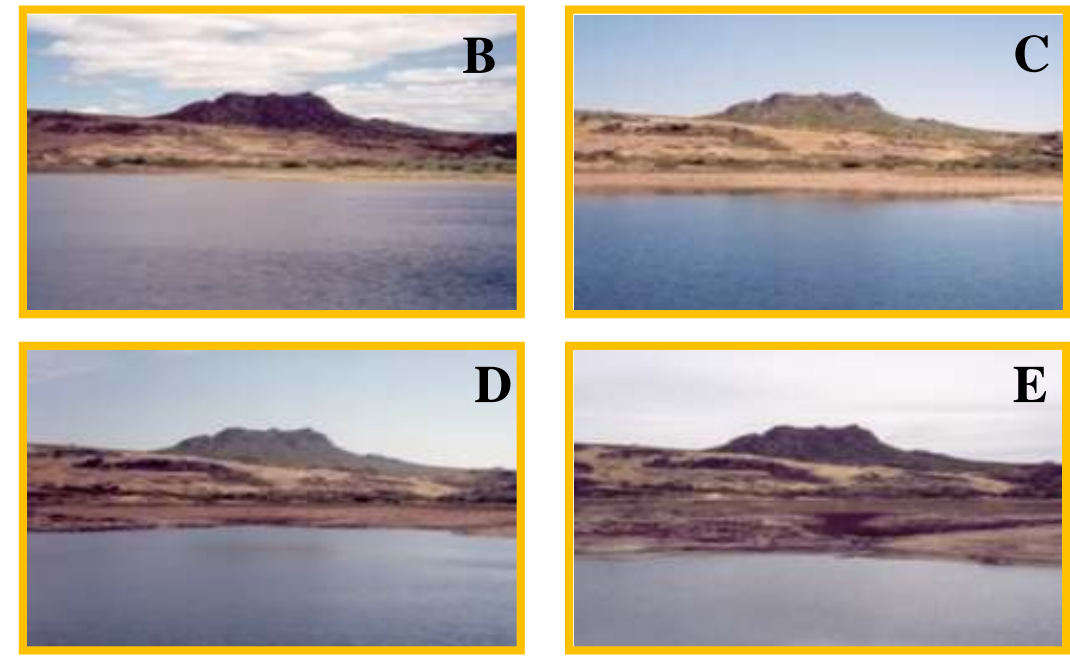

D

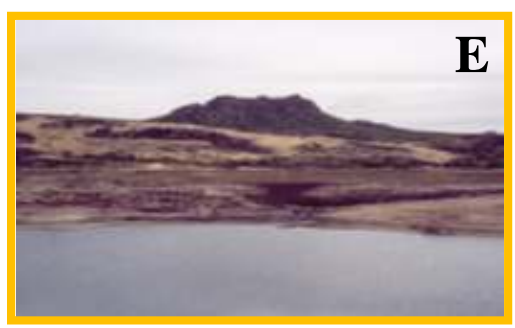

Fig. 2. Pattern of water level fluctuations during the study period (A). Water level in: (B) Winter; Spring (C); early Summer (D) and late (E) Source of A: [14] 
area is very often subjected to wild fires mainly induced by shepherds to obtain better grazing. Further information concerning morphological and hydrological characteristics of this reservoir can be found in [15].

\subsection{Field Sampling and Laboratory Analysis}

Water samples were collected monthly in winter and biweekly in summer, from January 2000 to December 2002 at one single sampling station, located at the deepest point of the reservoir. Both, in 2010 and in 2015 samples were obtained seasonally. Main trends in zooplankton and environmental variables were analysed on the basis of three hydrological phases: the maximum level phase, the emptying phase and the minimum level phase. The total phosphorus (TP), chlorophyll a (CHL a) and water transparency were determined to evaluate the reservoir trophic state according to [16] and also the changes in it across the reservoir hydrological cycle. Carlson's Trophic Index was computed from Secchi disk transparency (TSI (SD)), TP concentrations (TSI (TP)) and $\mathrm{CHL}$ concentrations (TSI (CHL)). All three components of the index were taken into account for a more complete interpretation of data, as in reservoirs inorganic seston is generally more abundant than organic particles [16]. The soluble reactive phosphorus (SRP) was also determined. Zooplankton samples were obtained on each sampling date with the help of two vertical hauls using a Wisconsin type net of $64 \mu \mathrm{m}$ mesh size. Animals were anaesthetised with carbonated water and preserved in sugar-saturated formaldehyde (4\% final concentration). Depending on the density, zooplankton samples were counted in $5,10,20 \mathrm{ml}$ sub-samples or in total. Animals were identified to the genus/ species level.

\subsection{Data Analysis}

To evaluate the association between taxa composition and environmental variables, a Redundancy Analysis (RDA) was performed. A linear model of ordination was used, because a preliminary Detrended Correspondence Analysis (DCA) resulted in turnovers $<2$ SD. According to [17], this is the recommended criterion for choosing linear models of ordination instead of uni-modal models. Relative abundance of the most representative zooplankton taxa were transformed to $\log (x+1)$. For the purpose of the statistical analyses, all Keratella species were retained in a single category. Environmental variables showing skewed distributions were also $\log (x+1)$ transformed. In RDA, a forward selection procedure was used to add significant explanatory variables to the model. Those were added in the order of the greatest additional contribution to the total variance explained. Statistical significance in RDA was assessed by Monte-Carlo permutation tests (9999 permutations). The computer program CANOCO version 4.5 was used to perform both the preliminary DCA and the RDA. A Kruskal-Wallis test was performed for each environmental variable to determine whether the mean values obtained at the maximum level phase, at the emptying phase and at the minimum level phase were significantly different. This statistical analysis was performed using SPSS 20. To illustrate the role of zooplankton as a valuable environmental indicator, several zooplankton metrics were studied: (1) The trophic state index of rotifer abundance [18]; (2) the ratio of crustacean abundance to rotifer abundance (NCrust/NRot) and (3) the ratio of large $(>10 \mu \mathrm{g})$ cladoceran abundance to total cladoceran group abundance (NLargeClad/NClad) [19].

\section{RESULTS}

\subsection{Zooplankton Community}

The present research identified: 13 taxa of Rotifera, 12 Cladocera and 3 Copepoda (Table 1). However, zooplankton community was dominated only a fewer species (10) (Table 2). Of all the zooplankton species found in $\mathrm{S}$. Serrada only the most representative were considered in the RDA.

The forward variable selection approach to the RDA revealed a strong influence of temperature $(P=0.005)$, and $\mathrm{CHL}$ a $(P=0.007)$, SRP $(P=$ $0.01)$ and TP $(P=0.03)$ concentrations, to the observed significant associations between the zooplankton assemblage and environmental variables (Monte-Carlo test; $P=0.005$ ). The ordination space defined by the first two RDA axis (Fig. 3) accounted for $84.2 \%$ of speciesenvironment relation and represented $25.4 \%$ of the variation in species data. The distribution of sample scores in this ordination space reflected a clear distinction between the maximum level phase and the emptying/minimum level phases. However, the distinction between the latter two phases was not so clear. Daphnia were associated with lower temperatures and the maximum level phase. Ceriodaphnia were clearly 
Table 1. Composition of the zooplankton community in S. Serrada

\begin{tabular}{|c|c|c|}
\hline Rotifera & Cladocera & Copepoda \\
\hline $\begin{array}{l}\text { Asplanchna priodonta Gosse, } \\
1850\end{array}$ & Alona affinis (Leydig, 1860) & $\begin{array}{l}\text { Eucyclops serrulatus } \\
\text { (Fischer, 1851) }\end{array}$ \\
\hline Collotheca sp. Harring, 1913 & Alona costata Sars, 1862 & $\begin{array}{l}\text { Macrocyclops albidus } \\
\text { (Jurine, 1820) }\end{array}$ \\
\hline Conochilus sp. Ehrenberg, 1834 & Alona quadrangularis (Müller, 1776) & $\begin{array}{l}\text { Tropocyclops prasinus } \\
\text { (Fischer, 1860) }\end{array}$ \\
\hline Euchlanis sp. Ehrenberg, 1832 & Coronatella rectangula (Sars, 1861) & Nauplii \\
\hline Gastropus sp. Imhof, 1888 & Alonella nana (Baird, 1850) & \\
\hline Hexarthra mira (Hudson, 1871) & Bosmina longirostris (Müller, 1776) & \\
\hline $\begin{array}{l}\text { Keratella cochlearis (Gosse, } \\
\text { 1851) }\end{array}$ & $\begin{array}{l}\text { Ceriodaphnia quadrangula (Müller, } \\
\text { 1785) }\end{array}$ & \\
\hline Keratella quadrata (Muller, 1786) & $\begin{array}{l}\text { Chydorus sphaericus (Mueller, } \\
\text { 1785) }\end{array}$ & \\
\hline $\begin{array}{l}\text { Keratella cochlearis tecta (Gosse, } \\
\text { 1851) }\end{array}$ & Daphnia longispina (Mueller, 1785) & \\
\hline Ploesoma hudsoni ( Imhof, 1891) & $\begin{array}{l}\text { Drepanothrix dentata (Eurén, } \\
\text { 1861) }\end{array}$ & \\
\hline Polyarthra sp. Ehrenberg, 1834 & $\begin{array}{l}\text { Holopedium gibberum }{ }^{\star} \text { Zaddach, } \\
1855\end{array}$ & \\
\hline $\begin{array}{l}\text { Synchaeta pectinata Ehrenberg, } \\
1832 \\
\text { Trichocerca sp. Lamarck, } 1801\end{array}$ & Simocephalus sp. Schoedler, 1858 & \\
\hline
\end{tabular}

Table 2. The most common taxa of the zooplankton community quantified using the mean $( \pm S D)$ of the relative abundances during: (1) the maximum level phase; (2) the emptying phase; and (3) the minimum level phase. Taxa abbreviations used in the RDA are indicated in brackets

\begin{tabular}{llll}
\hline & $\mathbf{1}$ & $\mathbf{2}$ & $\mathbf{3}$ \\
\hline Rotifera & $68.43 \pm 33.23$ & $30.37 \pm 28.65$ & $47.57 \pm 23.72$ \\
Cladocera & $19.46 \pm 23.22$ & $19.46 \pm 22.58$ & $11.28 \pm 7.81$ \\
Copepoda & $13.71 \pm 18.05$ & $50.17 \pm 28.46$ & $40.00 \pm 23.36$ \\
Rotifera & & & \\
Asplanchna (Aspl.) & $20.89 \pm 29.48$ & $4.37 \pm 8.92$ & $6.03 \pm 12.33$ \\
Conochilus (Cono.) & $26.46 \pm 33.55$ & $2.59 \pm 7.46$ & $3.67 \pm 6.40$ \\
Gastropus (Gast.) & $0.21 \pm 0.83$ & $0.47 \pm 1.72$ & $0.35 \pm 0.63$ \\
Hexarthra. (Hexa.) & $0.05 \pm 0.15$ & $1.08 \pm 1.72$ & $0.19 \pm 0.60$ \\
Keratella (Kera.) & $7.38 \pm 14.04$ & $16.82 \pm 28.21$ & $16.06 \pm 24.05$ \\
Polyarthra(Poly.) & $12.15 \pm 25.64$ & $1.15 \pm 2.08$ & $6.42 \pm 10.30$ \\
Synchaeta (Sync.) & $2.20 \pm 4.70$ & $2.63 \pm 3.84$ & $17.83 \pm 19.74$ \\
Cladocera & & & \\
Ceriodaphnia (Cqua.) & $6.97 \pm 18.41$ & $22.17 \pm 24.89$ & $7.71 \pm 8.19$ \\
Daphnia (Dlon.) & $4.94 \pm 13.37$ & $0.42 \pm 0.76$ & $1.90 \pm 2.31$ \\
Copepoda & & & \\
Tropocyclops (Tpra.) & $6.82 \pm 15.33$ & $17.43 \pm 22.30$ & $26.76 \pm 30.55$ \\
Nauplii (Naup) & $11.93 \pm 19.76$ & $30.87 \pm 28.53$ & $13.00 \pm 13.42$ \\
\hline
\end{tabular}

related to the emptying phase, when temperature was higher. Conochilus and Asplanchna were associated with low values of TP and $\mathrm{CHL}$ a (maximum level phase). Polyarthra abundance was also high during this period. However, in the ordination space, this species was associated with high concentrations of TP. In fact, the abundance of this rotifer was higher after strong rain events when TP concentrations concomitantly 
increased. Gastropus, Keratella, Hexarthra, T. prasinus and nauplii abundances were related to the increase in the system instability and to the higher TP and CHL a concentrations during the emptying and the minimum level phases.

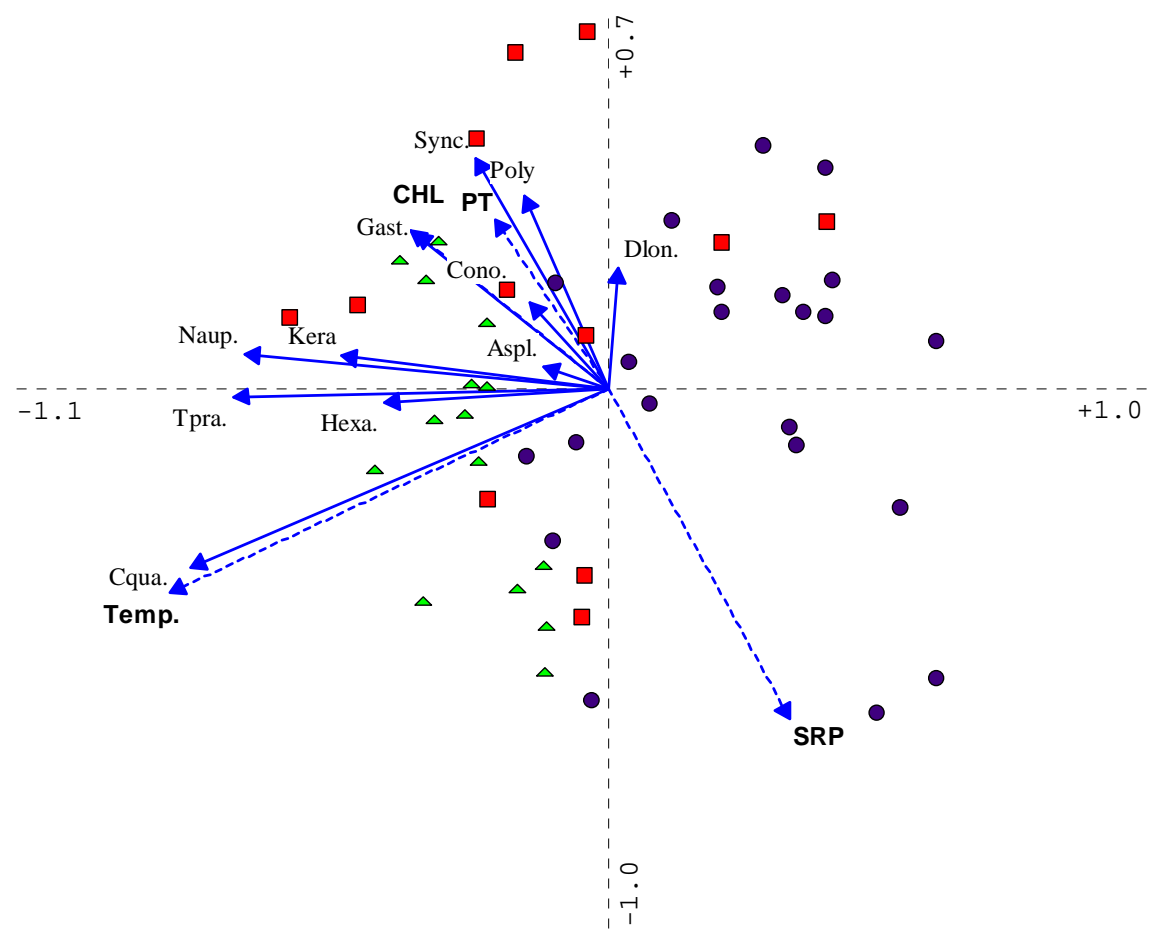

Fig. 3. RDA ordination diagram depicting the effects of environmental variables on Zooplankton community. Circles are the scatters for samples taken at the maximum level phase; triangles are the scatters for samples taken at the emptying phase and squares are the scatters for samples taken at the minimum level phase. Dashed arrows are the species and solid arrows are the environmental variables evidencing significant correlations with the canonical axes. Codes for environmental variables are given in Table 3, codes of zooplankton are given in Table 2

Table 3. Mean \pm SD values of the environmental variables and minimum-maximum range for $\mathrm{pH}$ obtained during the maximum level phase (1), the emptying phase (2) and the minimum level phase (3), and the results of the Kruskal-Wallis test. Abbreviations used in the RDA are indicated in brackets

\begin{tabular}{|c|c|c|c|c|}
\hline Variables & 1 & 2 & 3 & $\mathbf{P}$ \\
\hline Water transparency $(\mathrm{m})($ Secc.) & $2.9 \pm 0.9$ & $2.9 \pm 1.0$ & $1.7 \pm 0.4$ & ** \\
\hline Water temperature ( $\left.{ }^{\circ} \mathrm{C}\right)$ (Temp.) & $9.3 \pm 5.5$ & $19.4 \pm 1.3$ & $10.2 \pm 4.1$ & ** \\
\hline Dissolved oxygen $\left(\mathrm{mgl}^{-1}\right)$ (DO) & $8.6 \pm 1.6$ & $8.4 \pm 0.9$ & $8.6 \pm 1.5$ & NS \\
\hline Conductivity $\left(\mu \mathrm{S} \mathrm{cm}{ }^{-1}\right)$ (Cond.) & $6.0 \pm 1.5$ & $8.3 \pm 0.8$ & $8.1 \pm 1.5$ & ** \\
\hline $\mathrm{pH}(\mathrm{PH})$ & $6.9-7.4$ & $5.4-8.1$ & $7.0-8.5$ & NS \\
\hline $\mathrm{N}-\mathrm{NO}_{3}\left(\mathrm{mg} \mathrm{l}^{-1}\right)\left(\mathrm{NO}_{3}\right)$ & $5.8 \pm 8.7$ & $0.9 \pm 0.8$ & $13.3 \pm 15.2$ & ** \\
\hline $\mathrm{N}-\mathrm{NH}_{4}\left(\mathrm{mg} \mathrm{l}^{-1}\right)\left(\mathrm{NH}_{4}\right)$ & $0.2 \pm 0.5$ & $0.1 \pm 0.2$ & $0.4 \pm 0.8$ & NS \\
\hline $\mathrm{TP}\left(\mu \mathrm{gl}^{-1}\right)(\mathrm{TP})$ & $59.9 \pm 25.3$ & $70.1 \pm 19.2$ & $82.0 \pm 11.4$ & ** \\
\hline $\operatorname{SRP}\left(\mu \mathrm{gl}^{-1}\right)(\mathrm{SRP})$ & $8.7 \pm 7.5$ & $6.6 \pm 4.7$ & $9.5 \pm 7.2$ & NS \\
\hline Chlorophyll a $\left(\mu \mathrm{g} \mathrm{I}^{-1}\right)(\mathrm{CHL}$ a) & $1.7 \pm 1.3$ & $1.9 \pm 1.6$ & $8.0 \pm 4.7$ & ** \\
\hline
\end{tabular}




\subsection{Environmental variables Carlson's Trophic State Index}

and

Mean TP, $\mathrm{N}-\mathrm{NO}_{3}$ and $\mathrm{CHL}$ a concentrations, and conductivity were the highest during the minimum level phase. On the other hand, water transparency was the lowest during the same period. SRP mean concentrations were also slightly higher during this period than during the other months of the year. However, those differences were not statistically significant. TP, conductivity and $\mathrm{CHL}$ a decreased during the maximum level phase. Mean $\mathrm{N}-\mathrm{NO}_{3}$ decreased during the emptying phase. $\mathrm{N}^{-\mathrm{NH}_{3}}$ concentrations were always below detection limits (Table 3). During the period of study and depending on precipitation intensity, S. Serrada reached the maximum level phase in one or two weeks. Thus, at the beginning of the maximum level phase, TP, $\mathrm{N}_{-} \mathrm{NO}_{3}$ and $\mathrm{CHL} a$ concentrations were high, decreasing afterwards.

According to Carlson's Trophic State Index, this reservoir is meso-eutrophic (with a tendency to increase in all components of the index towards the emptying and minimum level phases) in all phases of its hydrological cycle (Table 4).

\subsection{Zooplankton Metrics}

The trophic state index for rotifer abundance also characterized the reservoir as meso-eutrophic. The other metrics (crustacean abundance to rotifer abundance and large Cladocera abundance to total Cladocera abundance) further supported the dominance of rotifers, which is typical of aquatic systems exposed to high levels of disturbance (Table 4). Despite of the rotifer dominance in all phases (except in the emptying) TSI $N$ rot increased in the low level phase, when TP, SRP and CHL a concentrations increased and water transparency decreased. Crustacean/ Rotifer ratio also followed the same variation pattern. Results for Large Cladocera/total
Cladocera ratio were not so elucidative. In fact, these results could also have been influenced by variations in water temperature. Daphnia prefer cold waters, whereas Ceriodaphnia prefer warm waters. In general, results obtained for Carlson's Trophic Index and for zooplankton metrics were all in the same line.

\section{DISCUSSION}

Actually, S. Serrada reservoir is a highly disturbed system. The increase in TP, SRP and $\mathrm{CHL}$ a concentrations and the decrease in water transparency during the emptying and minimum level phases could have been a consequence of the increment of suspended particulate material in the water column. This must be due to the water turbulence generated during the emptying phase, plus the disruption of stratification at the end of this phase. Moreover, the exposure of littoral sediments to cycles of drying and wetting, as a consequence of water level fluctuations, could have had implications on nutrient cycling, namely on phosphorus availability. In fact, in reservoirs where water level fluctuations were accentuated and where refilling has taken place over a short period of time, littoral sediments that were periodically exposed during cycles of drying and wetting have less capacity to adsorb nutrients than those that remained inundated $[20,21,3,4,5]$.

Despite of the high internal disturbance, zooplankton community has several rare species (in the context of Iberian Peninsula) such as Drepanothrix dentata, Ceriodaphnia quadrangula and Holopedium gibberum. Holopedium (typical of oligotrophic waters) was only detected in and after 2010 [22]. However, the community is always dominated by rotifers and other specialists in small particle feeding, whose food preferences are mostly comprised of detritusbacteria and phytoplankton. Most zooplankters

Table 4. Mean \pm SD values of Carlson's Trophic State Index and of zooplankton metrics range for $\mathrm{pH}$ obtained during the maximum level phase (1), the emptying phase (2) and the minimum level phase (3)

\begin{tabular}{llll}
\hline & $\mathbf{1}$ & $\mathbf{2}$ & $\mathbf{3}$ \\
\hline Carlson's trophic index & & & \\
TSI (SD) & $45.5 \pm 5.0$ & $45.5 \pm 6.0$ & $53.1 \pm 3.8$ \\
TSI (TP) & $62.0 \pm 6.0$ & $64.9 \pm 4.1$ & $67.6 \pm 2.2$ \\
TSI (CHL) & $31.4 \pm 10.4$ & $33.9 \pm 9.9$ & $49.7 \pm 5.2$ \\
Zooplankton metrics & & & \\
TSI $_{\text {r rot }}$ & $63.0 \pm 12.1$ & $65.5 \pm 8.3$ & $70.3 \pm 7.2$ \\
Ncrus/Nrot & $5.5 \pm 19.4$ & $15.0 \pm 33.5$ & $2.8 \pm 6.1$ \\
NLargeClad/NClad & $0.3 \pm 0.3$ & $0.1 \pm 0.2$ & $0.4 \pm 0.4$ \\
\hline
\end{tabular}


including Ceriodaphnia and T. prasinus, can only take particles smaller than $20 \mu \mathrm{m}$ [23]. Those assemblage patterns are typical in reservoirs subjected to periodic water level variations [24, $25,12,13]$. According to these authors, the above mentioned species evidence adaptive advantages over larger Cladocera and Copepoda, not only on account of their feeding behaviour but also because they have shorter generation times and greater tolerance to large amounts of organic matter in the water. An exception was Conochilus, which according to [26], is typically associated with environments poor in organic matter. The low abundance of large herbivorous zooplankton, such as Daphnia and other large Cladocera, concomitantly with the dominance of Rotifera and small Cladocera, is one of the indicators of the trophic state and water quality. Large Cladocera abundance decreases in parallel with increasing of trophic state, showing the high indicative ability of zooplankton to reflect the ecological integrity of ecosystem and water quality. Similar results were obtained by $[7,19]$.

\section{CONCLUSION}

The present research has shown that zooplankton community has indicative ability. When the system was more oligotrophic (maximum level phase), indicatory species of oligotrophic waters, such as Daphnia longispina, Holopedium and Conochilus increased their densities; when the system became more eutrophic (emptying phase and minimum level phase) the dominant taxa were typical of eutrophic waters, such as Keratella, Gastropus and $T$. prasinus. These trends were also reflected by zooplankton metrics, which were in line with Carlson's Trophic State Index.

\section{ACKNOWLEDGEMENTS}

To the anonymous reviewers, whose suggestions helped us to improve the present manuscript.

\section{COMPETING INTERESTS}

Authors have declared that no competing interests exist.

\section{REFERENCES}

1. Wetzel RG. Reservoir Ecosystems: Conclusions and speculations. In: KW
Thornton, BL Kimmel, Payne FE. editors. Reservoir limonology. Ecological Perspectives. New York: Wiley; 1990.

2. Naselli-Flores L, Barone R. Water-level fluctuations in Mediterranean reservoirs: Setting a dewatering threshold as a management tool to improve water quality. Hydrobiologia. 2005;548:85-99.

3. Zohary T, Ostrovsky I. Ecological impacts of excessive water level fluctuations in stratified freshwater lakes. Inland Waters. 2011;1:47-59.

4. Zhang B, Guo JS, Fang F, Li, Fu C. Concentration of nutrients in the soil in water-level-fluctuating zone of Three Gorges Reservoir. Ecohydrology \& Hydrobiology. 2012;12(2):105-14.

5. Krolová M, Cížková M, Hejzlar J, Poláková S. Response of littoral macrophytes to water level fluctuations in a storage reservoir. Knowledge and Management of Aquatic Ecosystems. 2013;408:07.

Available:http://dx.doi.org/10.1051/kmae/2 $\underline{013042}$

6. Valeriano-Riveros ME, Vilaclara G, Castillo-Sandoval FS, Merinolbarra $M$. Phytoplankton composition changes during water level fluctuations in a high-altitude tropical reservoir. Inland Waters. 2014;4:337-48.

7. Jeppesen $E$, Nõges $P$, Davidson TA, Haberman J, Nõges T, Blank $K$, et al. Zooplankton as indicators in lakes: $A$ scientific-based plea for including zooplankton in the ecological quality assessment of lakes according to the european water framework directive (WFD). Hydrobiologia. 2011;676:279-97.

8. Boavida MJ, Crispim MC. Study of zooplankton populations as a 35-year reservoir is being emptied. Verh. Internat. Verein. Limnol. 1993;25:1204-206.

9. Crispim MC, Boavida MJ. Comparison of rotifer communities in Maranhão reservoir (Portugal) before its complete emptying and on refilling. Hydrobiologia. 1995; 313/314:325-32.

10. Geraldes AM. Boavida MJ. Seasonal water level fluctuations: Implications for reservoir limnology and management. Lakes Reserv Res Manage. 2005;10:59-69.

11. Mac Donagh ME, Casco MA, Claps MC. Plankton relationships under small water level fluctuations in a subtropical reservoir. Aquatic Ecology. 2009;43(2):371-381. 
12. Olds BP, Peterson BC, Koupal KD, Schoenebeck CW, Farnsworth-Hoback KM, Hoback WW. Zooplankton density increases in an irrigation reservoir during drought conditions. Trans Nebr Acad Sci. 2014;34:27-32.

13. DeBoer JA, Webber CM, Dixon TA, Pope KL. The influence of a severe reservoir drawdown on springtime zooplankton and larval fish assemblages in red willow Reservoir, Nebraska. Journal of Freshwater Ecology. 2016;31(1):131-46.

14. SNIRH. Dados sintetizados: Características das albufeiras;1995-2016. Available:http://snirh.pt/index.php?idMain= 1\&idltem $=7$

(Accessed 22 November 2016)

15. Geraldes AM, Boavida MJ. Distinct age and landscape influence on two reservoirs under the same climate. Hydrobiologia. 2003;504:277-88.

16. Carlson RE. A trophic state index for lakes. Limnol. Oceanogr. 1977;22:361-69.

Available:http://aslo.net/lo/toc/vol 22/issue 2/0361.pdf

17. Ter Braak CJF. Ordination. In: Jongman RHG, Ter Braak CJF, van Tongeren OFR, editors. Data analysis in community and landscape ecology. Cambrige: University press; 1995.

18. Ejsmont-Karabin J. The usefulness of zooplankton as a lake ecosystem indicator: Rotifer trophic index. Pol. J. Ecol. 2012;60:339-50.
19. Haberman J, Haldna M. Indices of zooplankton community as valuable tools in assessing the trophic state and water quality of eutrophic lakes: Long term study of Lake Võrtsjärv. J. Limnol. 2014; 73(2):263-73.

20. Fabre A. Experimental studies on some factors influencing phosphorus solubilisation in connection with the drawdown of a reservoir. Hydrobiologia. 1988;159:153-158.

21. Watts CJ. Seasonal phosphorus release from exposed, re-inundated littoral sediments of two Australian reservoirs. Hydrobiologia. 2000;431:27-39.

22. Geraldes AM, Alonso M. Bosmina (Eubosmina) coregoni Baird, 1857 (Crustacea, Branchiopoda, Anomopoda): New plankton invader in the Iberian Peninsula. Graellsia. 2014;70(2):1-8.

23. Lampert W. Sommer U. Limnoecology the ecology of lakes and streams. New York: Oxford University Press; 1997.

24. Schmid-Araya JM, Zuñiga LR. Zooplankton community structure in two Chilean reservoirs. Arch Hydrobiol. 1992;123: 305-35.

25. Gal G, Skerjanec M, Atanasova N. Fluctuations in water level and the dynamics of zooplankton: A data-driven modelling approach. Freshwater Biology. 2013;58(4):800-816.

26. Sladeček $\mathrm{V}$. Rotifers as indicators of water quality. Hydrobiologia. 1983;100:169-201.

(c) 2016 Geraldes and Pasupuleti; This is an Open Access article distributed under the terms of the Creative Commons Attribution License (http://creativecommons.org/licenses/by/4.0), which permits unrestricted use, distribution, and reproduction in any medium, provided the original work is properly cited.

Peer-review history:

The peer review history for this paper can be accessed here: http://sciencedomain.org/review-history/17320 